\title{
PENINGKATAN KEMAMPUAN KOSAKATA BAHASA INGGRIS MELALUI METODE BERCERITA DENAN PETA PIKIRAN
}

\author{
Arie Rijanti \\ STAI Darunnajah Jakarta \\ rijanti2902@gmail.com
}

\begin{abstract}
Improving English Vocabulary Skills Through Storytelling Method With Mind Maps. The action research was conducted at SDN Tugu IX Cimanggis Depok, Thesis, Jakarta, PPS UNJ, 2011. The purpose of this study was to find out: how the learning process is to improve students' English vocabulary skills through the storytelling method with mind maps. This research was conducted at SDN Tugu IX Cimanggis Depok with research subjects as many as 38 second grade students. This research uses action research according to Kemmis and Mc Taggart. The results of the study show that through storytelling activities with mind maps in learning English can improve English vocabulary skills of second grade elementary school students
\end{abstract}

Keywords: Vocabulary, English, SDN Tugu IX Cimanggis Depok

\begin{abstract}
ABSTRAK
Peningkatan Kemampuan Kosakata Bahasa Inggris Melalui Metode Bercerita Dengan Peta Pikiran. Penelitian tindakan yang dilaksanakan di SDN Tugu IX Cimanggis Depok, Tesis, Jakarta, PPS UNJ, 2011. Tujuan penelitian ini adalah mengetahui: bagaimana proses pembelajaran untuk meningkatkan kemampuan kosakata Bahasa Inggris siswa melalui metode bercerita dengan peta pikiran.Penelitian ini dilakukan di SDN Tugu IX Cimanggis Depok dengan subjek penelitian sebanyak 38 orang siswa kelas II. Penelitian ini menggunakan penelitian tindakan menurut Kemmis and Mc taggart. Hasil penelitian menunjukkan melalui kegiatan bercerita dengan peta pikiran dalam pembelajaran Bahasa Inggris dapat meningkatkan kemampuan kosakata bahasa Inggris siswa kelas II SD
\end{abstract}

Kata Kunci : Kosakata, bahasa Inggris, SDN Tugu IX Cimanggis Depok 


\section{PENDAHULUAN}

Perkembangan dalam ilmu pengetahuan dan teknologi serta penyebaran informasi pada era globalisasi ini tidak dapat dipisahkan dari keterampilan menggunakan bahasa asing. Salah satu bahasa asing yang digunakan adalah Bahasa Inggris yang merupakan bahasa pertama di Amerika. Bahasa Inggris dikatakan sebagai bahasa internasional dan merupakan salah satu bahasa resmi di Organisasi Internasional seperti PBB dan Komite Olimpiade Internasional serta bahasa resmi diberbagai Negara.

Sementara itu sebagian besar masyarakat di Indonesia semakin merasa bahwa penggunaan Bahasa Inggris ada di mana-mana seperti di televisi, komputer, perpustakaan, sekolah dan juga sebagai syarat melanjutkan studi dan memperoleh pekerjaan ataupun promosi pekerjaan. Sehubungan dengan hal tersebut maka belakangan ini kursus bahasa asing terutama Bahasa Inggris kian marak dan ditujukan tidak hanya untuk orang dewasa, tetapi juga untuk anakanak. Lembaga prasekolah pun tidak mau ketinggalan zaman, pengajaran Bahasa Inggris yang semula hanya dikenal ditingkat SLTP, kini diberikan kepada siswa SD, bahkan siswa Taman Kanak-Kanak.

Dalam mempelajari bahasa Inggris, hal mendasar yang perlu dipelajari adalah kosakatanya. Pemahaman dalam mempelajari kosakata bahasa Inggris tersebut sebaiknya dilakukan sejak usia dini khususnya usia 6-12 tahun yang merupakan masa emas untuk belajar bahasa selain bahasa pertamanya. Di beberapa SD atau MI pelajaran bahasa Inggris sudah mulai diberikan di kelas I. Pelajaran bahasa Inggris ini dimuat dalam Kurikulum Tingkat Satuan Pendidikan (KTSP) yang dimasukkan ke dalam muatan lokal (mulok). Mulok merupakan kegiatan kurikuler untuk mengembangkan kompetensi yang disesuaikan dengan ciri khas dan potensi daerah, termasuk keunggulan daerah, yang materinya tidak dapat dikelompokkan ke dalam mata pelajaran yang ada. Muatan lokal bahasa Inggris wajib bagi semua siswa kelas I hingga kelas VI, dengan alokasi waktu yang diperlukan dua jam pelajaran. Permendiknas No. 22 dan 23, 2006 ,p. 18.).

Dalam silabus bahasa Inggris untuk siswa SD, ada beberapa standar kompetensi yang dipelajari diantaranya, mendengarkan, berbicara dan membaca (Yohanes Pancaran, 2009, pp. 1-14)

Kompetensi dasar dalam mendengarkan yaitu mengidentifikasi bunyi lafal kata, frase, atau kalimat yang diucapkan. Contohnya mampu menirukan kata salam (greetings), mampu melafalkan dan menjawab salam dengan benar. Kompetensi dasar dalam berbicara yaitu melafalkan kata dengan benar. Contohnya mampu mengucapkan salam, menjawab ucapan salam, mampu mengucapkan salam dengan benar, mampu berdialog secara sederhana. Sedangkan kompetensi dasar dalam membaca yaitu memahami tulisan Bahasa Inggris sangat sederhana dalam konteks kelas. Contohnya mampu membaca teks sederhana dengan pengucapan atau pronounciation yang benar.

\section{METODE PENELITIAN}

Penelitian ini menggunakan metode penelitian tindakan (action research) yang merupakan penelitian sistematik untuk menjawab masalah sosial yang berkembang, simultan dan menjurus kepada terwujudnya suatu perbaikan sistem yang dilakukan dalam bentuk perbaikan terstruktur melalui kajian perencanaan, tindakan, observasi, refleksi dan penggulangan perencanaan. (Siswoyo Hardidjodipuro, 1995, pp.8-10) 
Tujuan penelitian ini adalah mengetahui: bagaimana proses pembelajaran untuk meningkatkan kemampuan kosakata Bahasa Inggris siswa melalui metode bercerita dengan peta pikiran.Penelitian ini dilakukan di SDN Tugu IX Cimanggis Depok dengan subjek penelitian sebanyak 38 orang siswa kelas II. Penelitian ini menggunakan penelitian tindakan menurut Kemmis and Mc taggart. Hasil penelitian menunjukkan melalui kegiatan bercerita dengan peta pikiran dalam pembelajaran Bahasa Inggris dapat meningkatkan kemampuan kosakata bahasa Inggris siswa kelas II SD

\section{HASIL DAN PEMBAHASAN \\ Pengertian Kosakata}

Buah pikiran seseorang hanya dapat dengan jelas dimengerti oleh orang lain jika diungkapkan dengan menggukan kosakata. Hal ini dipertegas oleh Tarigan yang berpendapat bahwa keterampilan berbahasa seseorang bergantung pada kuantitas dan kualitas kosakata yang dimiliki. Semakin baik kualitas kosakata dan semakin banyak jumlahnya semakin besar pula kemungkinan seseorang terampil berbahasa. (Henry Guntur Tarigan, 1993, p. 3)

Ronald Carter and Michael Mc Carthy menyatakan bahwa kosakata adalah keseluruhan kata yang digunakan seseorang dalam kegiatan komunikasi. (Ronald carter and Michael Mc Carthy, 1988, p. 11.)

Perkembangan kosakata sangat penting dalam belajar membaca. Jumlah kata-kata dengan arti berbeda yang diketahui anak dapat mempengaruhi kemampuan membaca. Semakin banyak jumlah kata-kata yang mereka ketahui, semakin mudah bagi mereka untuk mengenalinya ketika membaca. Demikian pula dalam menulis, mengetahui banyak kosakata dengan beragam arti merupakan syarat penting dalam menulis.Meskipun struktur kalimat dan kemampuan berbahasa membuat menulis menjadi lebih menarik dan jelas. (Carol J. Fisher and C.Ann Terry, 1990, pp.139-143.)

Dalam jurnal yang sama, Lewis yang dikutip oleh Moras (2001) menyatakan bahwa kosakata harus menjadi pusat pembelajaran bahasa karena merupakan proses yang rumit. Guru harus dapat mengatur proses pembelajaran sehingga siswa dapat memenuhi target kosakata yang harus dipelajari.

Dari beberapa pernyataan di atas nampak bahwa pembelajaran kosakata sangatlah penting dan juga mempunyai pengaruh dalam belajar membaca dan juga menulis. Dengan meningkatkan kosakata yang kita miliki kita akan lebih mudah memahami isi sebuah tulisan maupun pesan atau buah pikiran yang disampaikan orang lain kepada kita maupun sebaliknya.

Pengertian Kosakata bahasa Inggris

Dalam Language Development for Preschool Children dikatakan bahwa mendengarkan adalah bagian terpenting dalam perkembangan bahasa. Anak-anak mendengar terlebih dahulu sebelum berbicara. Mendengarkan meliputi pengenalan suara, mengartikannya dan memberikan reaksi, Membaca adalah proses berfikir dan merupakan suatu proses yang membutuhkan banyak stimulasi, Berbicara dan mendengar merupakan komunikasi dua arah secara langsung dan menulis merupakan alat untuk berkomunikasi atau menyampaikan ide. (Reeta Sonawat and Jasmine Maria Francis, 2007, pp. 33-45.)

Brown dan Payne menyatakan lima langkah penting dalam pembelajaran kosakata: (1) mempunyai sumber agar dapat menemukan kata-kata baru. Diantaranya mempelajari kata-kata baru dari membaca buku, mendengarkan radio dan TV dan membaca Koran atau majalah.(2) mendapatkan gambaran yang jelas 
dari bentuk kata baru yang dipelajari baik secara visual dan pendengaran atau keduanya, (3) mempelajari arti dari kata-kata tersebut, (4) mengingat bentuk dan arti kata-kata yang telah dipelajari, dan terakhir (5) gunakan kata-kata tersebut.

(Evelyn Hatch and Cheryl Brown, 1995), p. 373.).

Pembelajaran Bahasa Inggris pada anak usia dini merupakan pembelajaran behasa kedua. Dalam mempelajari bahasa kedua anak akan mengalami kesulitan apabila tidak mendapatkan bimbingan dan bantuan dari orang-orang dewasa atau anak-anak yang lebih terampil. Ellis (1986) menyatakan bahwa bahasa pertama yaitu bahasa ibu atau bahasa yang lebih dahulu diperoleh mempunyai pengaruh terhadap proses penguasaan bahasa kedua pembelajar. Abdul Chaer, 2007, p. 256).

Menurut teori stimulus respons yang dikemukakan oleh kaum behaviorisme, bahasa adalah hasil perilaku stimulus respon Maka apabila seorang pembelajar ingin memperbanyak penggunaan ujaran, dia harus memperbanyak penerimaan stimulus. Selama sipembelajar belum mendapat stimulus selama itu pula dia belum dapat melakukan aktivitas respon.

Menurut teori kontrastif keberhasilan belajar bahasa kedua sedikit banyaknya ditentukan oleh keadaan linguistik bahasa yang telah dikuasai sebelumnya oleh si pembelajar (klein:1986). Berbahasa kedua adalah proses transferisasi. Maka jika bahasa pertama yang telah dikuasai banyak mempunyai kesamaan dengan bahasa yang dipelajari, akan terjadi semacam pemudahan dalam proses transferisasinya, Sebaliknya jika memiliki perbedaan maka akan terjadi kesulitan bagi pembelajar untuk menguasai bahasa kedua.

Dulay (1985) menyatakan bahwa kualitas lingkungan bahasa sangat penting bagi seorang pembelajar untuk dapat berhasil dalam mempelajari bahasa baru (bahasa kedua). Tjohjono, 1990) Yang dimaksud dengan lingkungan bahasa adalah segala hal yang didengar dan dilihat oleh pembelajar sehubungan bahasa kedua yang telah dipelajari seperti situasi di restoran atau toko, percakapan dengan kawan-kawan, ketika menonton TV, saat membaca Koran, dalam proses belajar mengajar di kelas, membaca buku pelajaran dan sebagainya.

Krashen membedakan dua lingkungan bahasa, yaitu (1) lingkungan formal, salah satu lingkungan dalam belajar yang memfokuskan pada penguasaan kaidah-kaidah bahasa yang sedang dipelajari secara sadar, seperti di kelas dalam proses belajar mengajar, (2) lingkungan informal, bersifat alami tidak dibuat-buat antara lain bahasa yang digunakan teman sebaya, bahasa pengasuh atau orang tua, bahasa yang digunakan anggota kelompok etnis pembelajar, yang digunakan media massa, bahasa para guru baik di kelas maupun di luar kelas.

Dari beberapa penjelasan dan definisi di atas dapat disimpulkan bahwa mempelajari bahasa kedua bagi anak harus dilihat dulu keadaan atau perkembangan bahasa pertamanya. Dalam pembelajaran bahasa kedua ini juga tidak terlepas dari bimbingan orang yang lebih ahli dan yang lebih penting lagi harus disesuaikan dengan usia si pembelajar. Bahasa kedua yang banyak dipelajari sekarang ini adalah Bahasa Inggris.

\section{Pengertian Bercerita}

Bercerita merupakan salah satu metode pembelajaran. Metode bercerita merupakan salah satu pemberian pengalaman belajar bagi anak dengan membawakan cerita kepada anak secara lisan. Cerita yang dibawakan harus menarik dan mengundang perhatian anak. Moeslichatoen, 2004, p. 157)

Cerita untuk anak juga mengandung nilai edukatif yaitu membangun perkembangan bahasa, mengembangkan kemampuan membaca, mengembangkan 
kepekaan terhadap cerita, membantu perkembangan aspek sosial, emosional, kreativitas dan kognitif.

Cerita yang akan disampaikan kepada anak-anak harus menggunakan bahasa yang mudah dimengerti oleh mereka. Cerita yang akan disampaikan juga harus berdasarkan tema atau situasi yeng disukai mereka untuk menghindari terjadinya kebosanan. Bercerita dengan menggunakan buku cerita nampak sering kita jumpai, namun kita juga harus memperhatikan pemilihan buku yang akan dibacakan. Buku yang baik memiliki bahasa yang benar-benar menyenangkan dan dapat membangun pengetahuan anak yang membaca ataupun mendengarkannya.

Chomsky menyatakan membacakan cerita dapat mengembangkan kemampuan berbahasa dan kosakata. (Shirly C. Raines, Robert J. Canady, Bill Martin,1990, p. 95.) Dari pernyataan tersebut nampak jelas bahwa membacakan cerita kepada anak membawa dampak yang sangat baik bagi perkembangan mereka, terutama perkembangan berbahasa dan kosakata.

\section{Pengertian Peta Pikiran (Mind Map)}

Mind map atau peta pikiran. Metode ini pertama kali dikembangkan oleh Tony Buzan. Beliau adalah penemu peta pikiran. Beliau mengatakan peta pikiran atau mind map adalah cara termudah untuk menempatkan informasi ke dalam otak dan mengambil informasi ke luar dari otak. Peta pikiran adalah cara mencatat yang kreatif, efektif dan secara harfiah akan memetakan pikiran-pikiran kita. (Tony Buzan, 2005, p.4)

Mind map atau peta pikiran merupakan metode visualisasi pengetahuan secara grafis untuk mengoptimalkan eksplorasi seluruh area kemampuan otak. (Femi Olivia dan Lita Ariani, 2009, p.25)

Semua mind map atau peta pikiran mempunyai kesamaan, pembuatannya menggunakan warna, memiliki struktur alami yang memancar dari pusat, menggunakan garis lengkung, symbol, kata dan gambar yang sesuai dengan satu rangkaian aturan yang sederhana, mendasar, alami dan sesuai dengan cara kerja otak.

Michael Michalko dalam bukunya Cracking Creativity yang dikutip oleh Tony Buzan menyatakan bahwa mind map atau peta pikiran akan mengaktifkan seluruh otak, membereskan akal dari kekusutan mental, memungkinkan untuk berfokus pada pokok bahasan, membantu menunjukkan hubungan antara bagianbagian informasi yang saling terpisah, memberi gambaran yang jelas pada keseluruhan dan perincian, memungkinkan untuk mengelompokkan konsep dan membantu membandingkannya, juga mensyaratkan untuk memusatkan perhatian pada pokok bahasan yang membantu mengalihkan informasi tentangnya dari ingatan jangka pendek ke ingatan jangka panjang.

Dalam mind map at work dikatakan mind map adalah bentuk penulisan catatan yang penuh warna dan bersifat visual, yang bisa dilakukan oleh satu orang atau sebuah tim yang terdiri atas beberapa orang.

Berdasarkan beberapa definisi diatas dapat di simpulkan bahwa mind map atau peta pikiran adalah cara menempatkan informasi ke dalam otak, membantu untuk tetap fokus dan dibuat dengan menggunakan gambar, simbol, kata dan garis yang berwarna sehingga lebih menarik dan untuk mempermudah mengingatnya kembali.

Pembuatan mind map atau peta pikiran menggunakan huruf, angka, warna dan gambar. Artinya cara ini melibatkan sisi kiri dan kanan otak. Tugas otak kiri 
termasuk kata-kata, logika, angka, urutan, daftar dan analisis. Istilah-istilah populer yang memayungi kegiatan belahan otak kiri adalah akademik, intelektual dan bisnis. Tugas otak kanan antara lain irama, kesadaran ruang, imajinasi, melamun, warna, dimensi dan tugas-tugas yang membutuhkan kesadaran holistik atau gambaran keseluruhan. Istilah popular yang memayungi belahan otak kanan adalah artistik, kreatif dan naluriah.

\section{KESIMPULAN}

1. Proses pembelajaran melalui kegiatan bercerita dengan peta pikiran yang dapat meningkatkan Kemampuan kosakata Bahasa Inggris siswa terdiri dari:

a. Menyampaikan tujuan dan tema cerita kepada siswa

b. Mengatur tata bahasa yang sesuai dengan cerita dan mudah dipahami, alat dan media yang diperlukan dalam bercerita

c. Memperkenalkan kosakata Bahasa Inggris kepada siswa melalui cerita yang dibacakan

d. Memperkenalkan cara pembuatan peta pikiran

e. Mengajak siswa untuk berpartisipasi dalam pembuatan peta pikiran

f. Mengaktifkan siswa dengan memberikan sejumlah pertanyaan yang dapat direspon secara langsung, memberikan stimulus agar mereka berani mengungkapkan atau menuliskan beberapa kosakata Bahasa Inggris yang telah mereka ketahui melalui cerita yang telah dibacakan.

2. Bagi siswa SD kelas II yang masih berada pada rentang usia anak usia dini, pembelajaran Bahasa Inggris melalui bercerita dengan peta pikiran tepat untuk dilakukan. Penggunaan buku cerita dengan gambar yang menarik dan berwarna membuat proses pembelajaran menarik bagi siswa. Pembuatan peta pikiran memudahkan anak untuk mengingat kata-kata yang ada dalam cerita yang telah dibacakan sehingga dapat meningkatkan kemampuan kosakata bahasa Inggris yang mereka miliki.

3. Hasil penelitian terhadap peningkatan kemampuan kosakata Bahasa Inggris siswa setelah diadakan tindakan menunjukkan peningkatan jumlah siswa yang mendapat nilai baik lebih dari $85 \%$.

4. Kemampuan kosakata Bahasa Inggris siswa meningkat secara signifikan setelah peneliti menggunakan strategi bercerita dengan peta pikiran.hal ini dapat dibuktikan dengan meningkatnya kosakata Bahasa inggris yang dimiliki siswa yang terdiri dari kemampuan mendengarkan (listening), membaca (reading), berbicara (speaking) dan menulis (writing)

\section{DAFTAR PUSTAKA}

Buzan, Tony. Mind Map at Work. Jakarta: PT. GRAMEDIA UTAMA, 2006

Mind Map. Jakarta: PT. Gramedia Pustaka Utama, 2005.

Carol J. Fisher and C, AnnTerry. Children Language and The Language Art. USD: A division Of Simon and Schuster inc, 1990.

Chaer, Abdul. Linguistik Umum. Jakarta: Rineka Cipta, 2007.

Psikolinguistik kajian Teoritik. Jakarta:Rineka Cipta, 2003.

Chandra, N. New Approach to Learner's Grammar. Singapur: SS MUBARUK \&BROSS PTE.LTD, 1994.

DEPDIKNAS. Pedoman Pembuatan cerita Anak Untuk taman kanak-kanak. Jakarta, 2006. 
Ella Faridati Zen. Bercerita Dalam Bimbingan Konseling. 2008 (http://ellafaridatizen.wordpress.com/2008/05/22/bercerita-dalambimbingan-konseling-seri-2/

Essa, Eva, Introduction to Early Childhood Education jilid 4, Delmar learning: 2004.

Evely Hatch and Cheryl Brown. Vocabulary, Semantic, and Language Education. USA: Cambridge University Press, 1995.

Hartati, sofia. Perkembangan Belajar Pada Anak Usia Dini. Jakarta: 2005.

IHF. Pendidikan yang Patut dan menyenangkan. Jakarta:2004.

JBPS FKIP et.al.LINGUA Jurnal Bahasa dan Sastra Volume 8. Palembang: Percetakan Sriwijaya, 2007.

Kadir, Statistika Untuk Penelitian Ilmu-ilmu Sosial. Jakarta: Rosemata Sampurna, 2010.

Kemmis, Stephen and Robin Mc taggart. Action Research Planner. Victoria Deakin University Press, 1988.

Lust, Barbara. Child language Acquisition and growth. US: Cambridge University Press, 2006.

Madya, Suwarsih. Teori dan Praktik penelitian Tindakan. Bandung: ALFABETA CV, 2007.

Maria Figueiredo, et.al. Concept Maps: Theory, Methodology, Technology. Spain,2004.

Meidya Derni. Bercerita Itu Mudah. 2009 (http://meidyaderni.com/?p=209).

Moeslichatoen, Metode pengajaran di Taman kanak-Kanak. Jakarta: DEPDIKBUD dan Rineka Cipta, 2004.

Nobert Schmitt and Michael McCharthy. Vocabulary Description, acquisition and pedagogy. New York: University Press, 2007.

Nurani Sujiono, Yuliani. Konsep dasar pendidikan anak Usia Dini. Jakarta: PT.Indeks, 2009.

Olivia, femi \& Lita Ariani. Belajar Membaca Yang Menyenangkan Untuk Anak Usia Dini. Jakarta: Media Komputindo, 2009.

Permendiknas No.22 dan 23. Model Kurikulum Tingkat Satuan Pendidikan (KTSP) SD \& MI, 2006.

Reeta Sonawat and Jasmine maria Francis. Language Development for Preeschool Children. Mumbai:Multi-tech publishing co, 2007.

Ronald carter and Michael McCharthy. Vocabulary and Language Teaching. London; Longman, 1988.

Santrock, John w. Life Span Development. Jakarta: Erlangga, 2002.

Sarwono, Sarlito.W. Berkenalan Dengan Aliran-aliran dan Tokoh-tokoh Psikologi. Jakarta : PT. Bulan Bintang, 2000.

Shirly C.Rains, Robert J. Canady, Bill Martin. The Whole Language Kindergarten. London: Teacher College Press, 1990.

Stanford Encyclopedy of Philosophy, (http://www.infed.org/thinkers/et-rous.htm)

Sujiono, Yuliani Nurani. Konsep Dasar Pendidikan anak Usia Dini. Jakarta: PT. INDEKS, 2009

Sukmadinata, Nana Syaodih. Metode Penelitian tindakan. bandung: Remaja Rossdakarya, 2005.

Suryadi. Cara Efektif Memahami Perilaku Anak Usia Dini. Jakarta: EDSA Mahkota, 2007.

Susan Sperry Smith. Early Childhood mathematics. USA: Pearson Inc, 2009. 
Peningkatan Kemampuan Kosakata ... I

Tarigan, Henry Guntur. pengajaran kosakata. Bandung: Angkasa, 2003.

Yuliani Nurani Sujiono dan Bambang Sujiono. Bermain Kreatif berbasis Kecerdasan jamak. Jakarta: PT. Indeks, 2010. 